九州大学学術情報リポジトリ

Kyushu University Institutional Repository

\title{
International Competitiveness of Indonesia' $s$ Cocoa Sector: From the Viewpoint of Product Differentiation
}

\section{ZIKRIA, Virda}

The former Laboratory of Quantitative Food Economic Analysis, Department of Agricultural and Resource Economics, Graduate School of Bioresource and Bioenvironmental Sciences, Kyushu University

\section{TAKAHASHI, Kohya}

Laboratory of Quantitative Food Economic Analysis, Division of Agricultural and Resource Economics, Department of Agricultural and Resource Economics, Faculty of Agriculture, Kyushu University

MAEDA, Koshi

Laboratory of Quantitative Food Economic Analysis, Division of Agricultural and Resource Economics, Department of Agricultural and Resource Economics, Faculty of Agriculture, Kyushu University

https://doi.org/10.5109/2339037

出版情報: 九州大学大学院農学研究院紀要. 64 (2)，pp.407-413，2019-09-02. Faculty of Agriculture, Kyushu University

バージョン :

権利関係 : 


\title{
International Competitiveness of Indonesia's Cocoa Sector: From the Viewpoint of Product Differentiation
}

\author{
Virda ZIKRIA ${ }^{1}$, Kohya TAKAHASHI and Koshi MAEDA* \\ Laboratory of Quantitative Food Economic Analysis, Division of Agricultural and Resource Economics, \\ Department of Agricultural and Resource Economics, Faculty of Agriculture, \\ Kyushu University, Fukuoka 819-0395, Japan \\ (Received May 7, 2019 and accepted May 8, 2019)
}

\begin{abstract}
Cocoa beans contribute a significant amount of foreign exchange earnings in Indonesia. However, Indonesia still lags behind other countries in terms of processed cocoa. Therefore, in April 2010, the Indonesian government stipulated a policy to increase the amount of processed cocoa for production and export. Since the introduction of this policy, Indonesia's processed cocoa export volume has increased; on the other hand, its cocoa bean exports have decreased. The objective of this study is to clarify the appropriateness of the policy by analyzing Indonesia's international competitiveness from the viewpoint of product differentiation. The main analysis results are as follows. First, Indonesia's cocoa bean and processed cocoa are both product differentiated from the other exporting countries' products, respectively. Second, the expenditure elasticities of Indonesia's cocoa bean and processed cocoa are the highest among all other export countries' corresponding products. Third, the policy change in 2010 significantly decreased (increased) the expenditure share of Indonesia's cocoa bean (processed cocoa) based on world demand. Fourth, it can be argued that the policy implemented by the Indonesian government is appropriate because Indonesia's processed cocoa shows greater potential for export expansion than cocoa bean.
\end{abstract}

Key words: Cocoa bean, Indonesia, Policy, Processed cocoa, Product differentiation

\section{INTRODUCTION}

Cocoa is one of the export commodities in Indonesia which contributes a lot to foreign exchange earnings. In order of export value in 2009, palm oil ranked first among Indonesian agricultural products, rubber ranked second, and cocoa bean ranked third, as shown in Table 1. Indonesia is one of the largest exporters of cocoa bean globally. Nonetheless, it lacks downstream industries that process the cocoa; as a result, the export value and volume of processed cocoa remains insufficient.

Therefore, the Indonesian government has attempted to increase the production and export of processed cocoa by introducing relevant policies, e.g., imposing an export tax on cocoa bean since April 2010 to restrict cocoa bean export. The policy stipulated by the Ministry

Table 1. Indonesia's Main Agricultural Sector Exports in 2009

\begin{tabular}{ccccc}
\hline Item & $\begin{array}{c}\text { Area } \\
\text { Harvested } \\
\text { (thousand ha) }\end{array}$ & $\begin{array}{c}\text { Production } \\
\text { Quantity } \\
\text { (thousand } \\
\text { ton) }\end{array}$ & $\begin{array}{c}\text { Export } \\
\text { Quantity } \\
\text { (thousand } \\
\text { ton) }\end{array}$ & $\begin{array}{c}\text { Export Value } \\
\text { (FOB base; } \\
\text { US\$ million) }\end{array}$ \\
\hline Palm oil & 5,370 & 90,000 & 16,829 & 10,367 \\
Rubber & 3,435 & 2,440 & 1,982 & 3,231 \\
Cocoa & 1,587 & 809 & 439 & 1,087 \\
Coffee & 1,266 & 682 & 510 & 822 \\
\hline
\end{tabular}

Data Source: FAOSTAT (2017)

1 The former Laboratory of Quantitative Food Economic Analysis, Department of Agricultural and Resource Economics, Graduate School of Bioresource and Bioenvironmental Sciences, Kyushu University

* Corresponding author (E-mail:kmaeda@agr.kyushu-u.ac.jp) of Finance (regulation number 67/PMK.011/2010) states that export commodities with a higher reference price will induce a higher tariff. Accordingly, commodities with price ranging from US $\$ 2,000-2,750$ per tonne are subject to $5 \%$ ad valorem tariff, US\$2,750-3,500 per tonne have $10 \%$ tariff, and above US $\$ 3,500$ per tonne have 15\% tariff (Indonesian Ministry of Finance, 2010). The policy aims to increase the availability of cocoa bean for domestic processing companies at an affordable price. This policy was implemented to develop the processed cocoa products' industry and to increase Indonesia's domestic value added, which contributes to national economic growth. Through this policy, Indonesia's volume of exported cocoa bean has decreased while that of processed cocoa has increased. The policy was apparently successful from a government and industry perspective, but disadvantaged farmers due to the decrease in total bean production. The total bean's production need to increase by increasing the export volume for both items to make farmers in advantage. Therefore, it is essential to analyze whether the policy that focuses on expanding processed cocoa export volume is appropriate or not.

Several studies have analyzed the competitiveness of Indonesian cocoa including Ragimun (2012) and Rifin (2013). Ragimun (2012) showed that Indonesia's cocoa remains relatively competitive using Revealed Competitive Advantage (RCA) analysis. Rifin (2013) clarified that Indonesia has a comparative advantage in producing cocoa beans, although the three other countries included in the study had higher RCA index, and analyzed global demand for Indonesia's cocoa bean. Although it is essential to analyze cocoa beans and processed cocoa simultaneously to evaluate the 2010 policy, they analyzed cocoa bean only. To address this limita- 
tion, we analyze not only cocoa bean but also processed cocoa.

The purpose of this study is to clarify the appropriateness of the policy imposed by the Indonesian government by analyzing the international competitiveness of Indonesia's cocoa bean and processed cocoa from the viewpoint of product differentiation. In addition, to account for varying characteristics across the world, we did not restrict the analysis to the demand of a specific country, but to global demand.

The remainder of this study is structured as follows. First, second chapter briefly describes cocoa and Indonesia's cocoa industry while third chapter introduces the model that was used in this study. Then, describes the data and their sources and fifth chapter outlines the estimation results. Next, discusses the demand of cocoa bean and processed cocoa. Finally, the last chapter highlights the conclusions of this study.

\section{COCOA AND INDONESIA'S COCOA INDUSTRY}

Indonesia has the potential to increase its cocoa production with the availability of plantation areas and arable land. Globally, Indonesia is one of the largest exporting countries of cocoa bean after Côte d'Ivoire and Ghana. Table 2 shows the countries that produce and export a significant volume of cocoa beans globally. As shown in Table 2, before 2010, Côte d'Ivoire ranked first, Ghana second, followed by Indonesia, Nigeria, and Cameroon in terms of both production and export volumes of cocoa beans.

Cocoa beans have two important impacts on Indonesia's economy. First, it is an important commodity, which provides export earnings and contributes to the national economy. Second, it serves as the primary source of the ingredient for the chocolate industry and its derivatives. Nonetheless, as the downstream industry in Indonesia remains underdeveloped, the country can only export cocoa beans and lags behind certain countries that are not the main producers of cocoa bean globally when it comes to processed cocoa products.

Table 3 shows the main exporting countries of processed cocoa. As shown in Table 3, before 2010, Netherlands had the highest volume of processed cocoa exports, followed by Côte d'Ivoire and Malaysia. In addition, Indonesia and Germany shifted between fourth and fifth positions. The World Cocoa Foundation (Indonesiainvestment, 2017) predicted that there would be an annual increase in global demand for cocoa. This estimated increase in global cocoa demand places Indonesia in a potentially favorable position as the country that is one of the largest producers and exporters of this com-

Table 2. Top Exporting Countries' Quantity of Cocoa Bean Produced and Exported (2006-2015)

\begin{tabular}{|c|c|c|c|c|c|c|c|c|c|c|c|}
\hline \multirow{2}{*}{ Countries } & \multicolumn{11}{|c|}{ Production Quantity (P) \& Export Quantity (E) (thousand ton) } \\
\hline & $\mathrm{P} / \mathrm{E}$ & 2006 & 2007 & 2008 & 2009 & 2010 & 2011 & 2012 & 2013 & 2014 & 2015 \\
\hline \multirow{2}{*}{ Côte d'Ivoire } & $\mathrm{P}$ & 1,408 & 1,229 & 1,382 & 1,223 & 1,301 & 1,511 & 1,486 & 1,449 & 1,442 & 1,484 \\
\hline & $\mathrm{E}$ & 925 & 804 & 783 & 918 & 791 & 1,073 & 1,011 & 814 & 1,117 & 1,286 \\
\hline \multirow{2}{*}{ Ghana } & $\mathrm{P}$ & 734 & 614 & 681 & 711 & 632 & 700 & 879 & 835 & 859 & 858 \\
\hline & $\mathrm{E}$ & 589 & 506 & 475 & 396 & 281 & 697 & 586 & 526 & 545 & 581 \\
\hline \multirow{2}{*}{ Indonesia } & $\mathrm{P}$ & 769 & 740 & 804 & 838 & 712 & 741 & 721 & 729 & 728 & 593 \\
\hline & $\mathrm{E}$ & 491 & 380 & 381 & 439 & 432 & 210 & 164 & 188 & 63 & 40 \\
\hline \multirow{2}{*}{ Nigeria } & $\mathrm{P}$ & 485 & 361 & 367 & 364 & 399 & 391 & 383 & 367 & 248 & 195 \\
\hline & $\mathrm{E}$ & 189 & 175 & 227 & 247 & 227 & 219 & 199 & 183 & 111 & 83 \\
\hline \multirow{2}{*}{ Cameroon } & $\mathrm{P}$ & 164 & 213 & 229 & 236 & 264 & 240 & 269 & 275 & 269 & 272 \\
\hline & $\mathrm{E}$ & 168 & 131 & 178 & 194 & 193 & 190 & 174 & 180 & 193 & 237 \\
\hline
\end{tabular}

Note: Within each country, the upper and lower rows show the production and export quantities, respectively.

Data Source: FAOSTAT (2017)

Table 3. Main Exporting Countries in terms of Processed Cocoa (2006-2015)

\begin{tabular}{crrrrrrrrrrr}
\hline \multirow{2}{*}{ Countries } & \multicolumn{10}{c}{ Export Quantity (thousand ton) } \\
\cline { 2 - 10 } & 2006 & 2007 & 2008 & 2009 & 2010 & 2011 & 2012 & 2013 & 2014 & 2015 \\
\hline Netherlands & 532 & 527 & 534 & 612 & 614 & 555 & 568 & 595 & 634 & 604 \\
Côte d'Ivoire & 205 & 217 & 234 & 243 & 242 & 225 & 242 & 209 & 336 & 315 \\
Malaysia & 207 & 236 & 253 & 224 & 241 & 300 & 248 & 255 & 236 & 242 \\
Germany & 89 & 101 & 114 & 138 & 187 & 211 & 189 & 205 & 236 & 251 \\
Indonesia & 107 & 106 & 120 & 83 & 103 & 179 & 197 & 196 & 242 & 287 \\
\hline
\end{tabular}

Data Source: FAOSTAT (2017) 
modity. However, Indonesia faces difficulties in increasing cocoa production.

Most of Indonesia's cocoa output is produced by smallholders with limited finances. Moreover, given the recent promising outlook of the palm oil and rubber industries, some Indonesian cocoa farmers have shifted their focus towards those commodities, potentially causing cocoa plantations to decline further in the coming years. Moreover, the majority of Indonesia's cocoa production has been exported in the form of raw cocoa beans. This has encouraged the government to stimulate national value-added processing industries. Hence, the Indonesian government issued a policy imposing export taxes for cocoa beans to encourage an increase in the export volume of processed cocoa. Resulting from this policy, the export volumes of cocoa beans and processed cocoa have changed, as shown in Tables 2 and 3 respectively. Specifically, while the production and export of cocoa beans has decreased, in contrast, the export of processed cocoa has increased gradually.

\section{MODEL}

To achieve the purpose of this study, we analyze global demand for cocoa beans and processed cocoa, respectively, using the Linear Approximate Almost Ideal Demand System (LA/AIDS) model of Deaton and Muellbauer (1980). The model is expressed as follows.

$$
w_{i t}=\alpha_{i}+\sum_{j=1}^{n} \gamma_{i j} \ln p_{j t}+\beta_{i} \ln \left(\frac{X_{t}}{P_{t}}\right)+d_{i} D M_{p o l i c y t}+v_{i t}
$$

Where $w_{i t}$ is the expenditure share of country $i, p_{j t}$ is the price of country $j, X_{t}$ is the total global expenditure, $P_{t}$ is the price index, $a_{i}, \gamma_{i j}, \beta_{i}$, and $d_{i}$ are estimating parameters, $v_{i t}$ is the error term, and $t$ refers to period $t$. Lastly, $D M_{\text {policy } t}$ is a dummy variable that takes value 0 in periods before the policy change (until 2010) and 1 thereafter (i.e., since 2011). We consider the effect of the policy change by examining the estimated volume and whether or not it is significant.

For the price index, we use the log-linear analog of the Laspeyres price index as follows.

$$
\ln P_{t}=\sum_{i=1}^{n} \bar{w}_{i} \ln p_{i t}
$$

Where $\bar{w}_{i t}$ is the sample mean of the expenditure share of country $i$.

In addition, the following parameter restrictions are imposed:

$$
\begin{aligned}
\sum_{i=1}^{n} \alpha_{i}=1, \sum_{i=1}^{n} \gamma_{i j} & =\sum_{i=1}^{n} \beta_{i}=\sum_{i=1}^{n} d_{i}=0 \text { (adding-up) } \\
\sum_{j=1}^{n} \gamma_{i j} & =0 \text { (homogeneity) } \\
\gamma_{i j} & =\gamma_{j i} \text { (symmetry) }
\end{aligned}
$$

\section{DATA}

We selected 36 countries $^{1}$ for cocoa bean and 52 countries $^{2}$ for processed cocoa as the import countries $^{3}$. For export countries, we select Indonesia, Côte d'Ivoire, Ghana, and the Rest of the World for cocoa bean, and Indonesia, Netherland, Côte d'Ivoire, and the Rest of the World for processed cocoa, as these countries together commanded the largest share of global exports from 1992 to 2015.

This study uses annual data from 1992 to $2015^{4}$. In processing the data, we need to calculate the real price of each country's product using exchange rates and the Consumer Price Index (CPI). While we analyze global demand in this study, each country contributing to global demand has different tendencies. Hence, before aggregating each country's data to global demand, we need to adjust the nominal price to account for change in price-levels and exchange rates, respectively.

Hence, similar to Konandreas et al. (1978) and Honma (1983), we convert nominal prices to real prices

1 Australia, Brazil, Canada, Chile, China, China Macau, Colombia, Croatia, Denmark, Finland, Germany, Greece, Hungary, India, Indonesia, Ireland, Japan, Kenya, Malaysia, Mexico, Netherlands, New Zealand, Portugal, Rep. of Korea, Romania, Saudi Arabia, Singapore, Spain, Sri Lanka, Sweden, Switzerland, Thailand, Trinidad and Tobago, Tunisia, Turkey, and USA.

2 Algeria, Australia, Bangladesh, Belize, Bolivia, Brazil, Brunei Darussalam, Canada, Chile, China, China Macau, Colombia, Croatia, Cyprus, Denmark, Finland, Germany, Greece, Guyana, Hungary, Iceland, India, Indonesia, Ireland, Jamaica, Japan, Kenya, Madagascar, Malaysia, Mexico, Myanmar, Netherlands, New Zealand, Oman, Paraguay, Peru, Portugal, Rep. of Korea, Romania, Saint Lucia, Saudi Arabia, Singapore, Spain, Sri Lanka, Sweden, Switzerland, Thailand, Trinidad and Tobago, Tunisia, Turkey, UAE, and USA.

3 The total countries' import number is based on the number of countries in 1992. Some countries were excluded from the analysis due to non-availability of CPI data or small volume or frequency of import. The non-availability may result from geographical separations and unions that occurred in those countries.

${ }^{4}$ We select 1992 as the starting period and 2015 as the ending period of analysis. In case of cocoa bean, we can obtain import data in 1992 for the 36 countries only, and the ratio of total volume of cocoa bean imported for 36 countries to volume of cocoa bean imported globally in 2015, which is the latest year that import data is available, reached more than $50 \%$ as follows. The countries that consisted in Rest of the World for cocoa bean and processed cocoa are different.

Cocoa bean:

Import quantity for the 36 countries in 2015

Import quantity for all countries in $2015>50 \%$

In the case of processed cocoa, the situation is similar, as shown below.

Processed cocoa:

Import quantity for the 52 countries in 2015

Import quantity for all countries in 2015 > $>50 \%$ 
as follow:

$$
R P_{i t}=\frac{N P_{i t}}{\frac{C P I_{i t}}{100} \times \frac{E R_{i t}^{0}}{E R_{i t}}}
$$

Where $R P_{i t}$ is the real price of country $i$ in year $t$, $N P_{i t}$ is the nominal price of country $i$ in year $t, E R^{0}{ }_{i t}$ is the exchange rate of country $i$ in base year (unit: national currency per US\$), $E R_{i t}$ is the exchange rate of country $i$ in year $t$ (unit: national currency per US\$). Additionally, the nominal price of country $i$ is obtained by dividing its nominal import value by its import quantity. The base year for CPI and exchange rate is 2000 .

Moreover, cocoa may be processed into three main products: cocoa paste ${ }^{5}$, cocoa powder ${ }^{6}$, and cocoa butter $^{7}$. The current conversion ratio is 1:1:1 (e.g., $100 \mathrm{MT}$ of paste is converted into $100 \mathrm{MT}$ of butter or $100 \mathrm{MT}$ of powder) (UTZ, 2017). Since each of the three items has the same mass, the volume and value data for the various forms of processed cocoa (paste, butter, and powder) are aggregated into a single item by simple aggregation (i.e., paste + butter + powder).

The necessary data for annual cocoa bean import with HS Code 1801 and processed cocoa import with HS Code 1803 (cocoa paste), 1804 (cocoa butter), and 1805 (cocoa powder) are obtained from United Nations (2017). Additionally, consumer price index (CPI) and exchange rate data are obtained from International Monetary Fund (2017). As the CPI data are not available for some years for several countries, we used the UN statistical year book for the missing data.

The sample mean and sample standard deviation of price, quantity, and expenditure share are presented in Table 4.

\section{ESTIMATION RESULTS}

We estimate the LA/AIDS model using iterative seemingly unrelated regression. Also, since the previous estimation implies a serial correlation in the error term of the demand system for processed cocoa, we assume that there is a first-order serial correlation in the error term $\left(v_{i t}=\rho v_{i t-1}+\varepsilon_{i t}\right)$ and estimate the processed cocoa equations using the methodology of Yen and Chern (1992) as follows.

$$
\begin{aligned}
w_{i t} & =\alpha_{i}+d_{i} D M_{\text {policy } t}+\sum_{j=1}^{n} \gamma_{i j} \ln p_{j t}+\beta_{i} \ln \left(\frac{X_{t}}{P_{t}}\right) \\
& -\rho\left[\alpha_{i}+d_{i} D M_{\text {policy } t-1}+\sum_{j=1}^{n} \gamma_{i j} \ln p_{j t-1}+\beta_{i} \ln \left(\frac{X_{t-1}}{P_{t-1}}\right)\right] \\
& +\rho w_{i t-1}+\varepsilon_{i t}
\end{aligned}
$$

Where $\rho$ is the estimating parameter and $\varepsilon_{i t}$ is a stochastic variable.

Tables 5 and 6 show the estimation results for cocoa bean and processed cocoa, respectively.

Based on the estimation results of cocoa bean, the coefficient of determination for Indonesia is 0.904 , Côte d'Ivoire is 0.886, and Ghana is 0.824. The estimation results for processed cocoa show that the coefficient of determination for Indonesia is 0.937, Netherlands is 0.991, and Côte d'Ivoire is 0.893 .

Moreover, based on the estimation results, the coefficients of the dummy variables in the share equations of Indonesia's cocoa bean and processed cocoa are significant with a value of -0.155 and 0.021 , respectively.

Furthermore, Table 7 shows the result of Marshallian price elasticity and expenditure elasticity of

\begin{tabular}{|c|c|c|c|c|c|c|}
\hline \multirow{2}{*}{$\begin{array}{l}\text { Mean (sd) } \\
\text { Countries }\end{array}$} & \multicolumn{3}{|c|}{ Cocoa Bean } & \multicolumn{3}{|c|}{ Processed Cocoa } \\
\hline & $\begin{array}{c}\text { Price } \\
\text { (US } \$ / \mathrm{kg})\end{array}$ & $\begin{array}{c}\text { Quantity } \\
\text { (thousand tons) }\end{array}$ & $\begin{array}{c}\text { Expenditure } \\
\text { Share }\end{array}$ & $\begin{array}{c}\text { Price } \\
(\mathrm{US} \$ / \mathrm{kg})\end{array}$ & $\begin{array}{c}\text { Quantity } \\
\text { (thousand tons) }\end{array}$ & $\begin{array}{c}\text { Expenditure } \\
\text { Share }\end{array}$ \\
\hline Indonesia & $\begin{array}{c}3.021 \\
(2.043)\end{array}$ & $\begin{array}{c}290.0 \\
(150.1)\end{array}$ & $\begin{array}{c}0.111 \\
(0.079)\end{array}$ & $\begin{array}{c}8.154 \\
(8.630)\end{array}$ & $\begin{array}{c}81.9 \\
(69.5)\end{array}$ & $\begin{array}{c}0.057 \\
(0.038)\end{array}$ \\
\hline Côte d'Ivoire & $\begin{array}{c}8.331 \\
(9.495)\end{array}$ & $\begin{array}{c}713.4 \\
(130.4)\end{array}$ & $\begin{array}{c}0.409 \\
(0.090)\end{array}$ & $\begin{array}{c}14.331 \\
(17.043)\end{array}$ & $\begin{array}{l}133.8 \\
(70.5)\end{array}$ & $\begin{array}{c}0.114 \\
(0.030)\end{array}$ \\
\hline Ghana & $\begin{array}{c}7.302 \\
(7.516)\end{array}$ & $\begin{array}{c}308.9 \\
(144.1)\end{array}$ & $\begin{array}{c}0.165 \\
(0.046)\end{array}$ & - & - & - \\
\hline Netherlands & - & - & - & $\begin{array}{c}21.783 \\
(24.629)\end{array}$ & $\begin{array}{l}260.7 \\
(49.3)\end{array}$ & $\begin{array}{c}0.363 \\
(0.138)\end{array}$ \\
\hline Rest of the World & $\begin{array}{c}7.760 \\
(9.023)\end{array}$ & $\begin{array}{c}563.5 \\
(192.8)\end{array}$ & $\begin{array}{c}0.315 \\
(0.060)\end{array}$ & $\begin{array}{c}10.619 \\
(10.593)\end{array}$ & $\begin{array}{c}519.9 \\
(151.3)\end{array}$ & $\begin{array}{c}0.465 \\
(0.083)\end{array}$ \\
\hline
\end{tabular}
demand for cocoa bean while Table 8 lists the corresponding result for processed cocoa.

Table 4. Sample Mean and Sample Standard Deviation of Price, Quantity, and Expenditure Share

Note: The table values represent sample means while the values in parentheses represent the sample standard deviations, respectively.

${ }^{5}$ Cocoa paste is solid, unsweetened baking chocolate made from ground cocoa nibs, which can be transformed into cocoa powder and cocoa butter.

${ }^{6}$ Cocoa powder is the solid product of the cocoa nib and can be processed to have varying fat content. The powder is used in beverages, baking, and frequently as a dye (Asselstine et al., 2016).

${ }^{7}$ Cocoa butter is the fat of the cocoa nib and may be used in lotions and pharmaceutical products (Spiegel, 2014). It is also the main ingredient in white chocolate. 
Table 5. Cocoa Bean Estimation Results

\begin{tabular}{ccccc}
\hline Parameter & $\mathrm{W}_{\mathrm{I}}$ & $\mathrm{W}_{\mathrm{C}}$ & $\mathrm{W}_{\mathrm{G}}$ & $\mathrm{W}_{\mathrm{R}}$ \\
\hline$\alpha_{i}$ & $-2.564^{* * *}$ & $4.545^{* * *}$ & $-1.417^{* *}$ & 0.436 \\
& $(-3.674)$ & $(5.357)$ & $(-2.466)$ & $(0.397)$ \\
$\beta_{i}$ & $0.129^{* * *}$ & $-0.196^{* * *}$ & $0.074^{* * *}$ & -0.007 \\
& $(3.947)$ & $(-4.934)$ & $(2.774)$ & $(-0.143)$ \\
$\alpha_{i}$ & $-0.155^{* * *}$ & $0.051^{* * *}$ & $0.033^{* * *}$ & 0.015 \\
& $(-10.633)$ & $(2.816)$ & $(2.833)$ & $(0.960)$ \\
$\gamma_{i I}$ & $0.072^{* * *}$ & & & \\
& $(8.506)$ & & & \\
$\gamma_{i C}$ & $-0.067 * * *$ & $0.152^{* * *}$ & & \\
& $(-6.333)$ & $(6.423)$ & & \\
$\gamma_{i G}$ & $0.024^{* * *}$ & -0.028 & 0.021 & \\
& $(2.232)$ & $(-1.169)$ & $(0.540)$ & \\
$\gamma_{i R}$ & $-0.029 * *$ & $-0.057^{* * *}$ & -0.017 & $0.103^{* * *}$ \\
$\mathrm{R}^{2}$ & $(-2.764)$ & $(-3.318)$ & $(-1.222)$ & $(4.578)$ \\
$\mathrm{DW}$ & 0.904 & 0.886 & 0.824 & \\
\hline
\end{tabular}

Note: 1) Values in parentheses represent the t value.

2) $R^{2}$ represents the coefficient of determination and DW represents the Durbin Watson statistic.

3) The critical value of the t distribution based on 54 degrees of freedom for the demand system is 1.674 at $10 \%$ level, 2.005 at 5\% level, and 2.670 at $1 \%$ level. Additionally, $* *$ and $* * *$ indicate that the estimated value is statistically significant at the $5 \%$ and $1 \%$ levels, respectively.

4) In column 1 , row $1, \mathrm{I}=$ Indonesia, $\mathrm{C}=$ Côte d'Ivoire, $\mathrm{G}=$ Ghana, $\mathrm{R}=$ Rest of the World.

5) The data from 1993 to 2015 is used for the estimation.

Table 6. Processed Cocoa Estimation Results

\begin{tabular}{ccccc}
\hline Parameter & $\mathrm{W}_{\mathrm{I}}$ & $\mathrm{W}_{\mathrm{N}}$ & $\mathrm{W}_{\mathrm{C}}$ & $\mathrm{W}_{\mathrm{R}}$ \\
\hline$\alpha_{i}$ & $-1.734^{* *}$ & $3.412^{* * *}$ & -0.664 & -0.015 \\
& $(-2.466)$ & $(3.332)$ & $(-0.861)$ & $(-0.013)$ \\
$\beta_{i}$ & $0.087^{* *}$ & $-0.150^{* * *}$ & 0.039 & 0.024 \\
& $(2.578)$ & $(-3.056)$ & $(1.042)$ & $(0.471)$ \\
$\alpha_{i}$ & $0.021^{* *}$ & -0.022 & -0.014 & 0.015 \\
& $(2.033)$ & $(-1.428)$ & $(-1.300)$ & $(0.960)$ \\
$\gamma_{i I}$ & $0.021^{* *}$ & $(2.228)$ & & \\
& $-0.029^{* * *}$ & $0.221^{* * *}$ & \\
$\gamma_{i N}$ & $(-4.256)$ & $(20.557)$ & \\
& 0.006 & $-0.035^{* * *}$ & $0.055^{* * *}$ \\
$\gamma_{i C}$ & $(0.866)$ & $(-4.746)$ & $(4.315)$ & \\
& 0.002 & $-0.157^{* * *}$ & $-0.026^{*}$ & $0.180^{* * *}$ \\
$\gamma_{i R}$ & $(0.171)$ & $(-13.006)$ & $(-1.837)$ & $(6.645)$ \\
& \multicolumn{5}{c}{$0.817^{* * *}$} \\
$\mathrm{R}^{2}$ & 0.937 & 0.991 & 0.893 \\
$\mathrm{DW}$ & 1.150 & 1.757 & 1.874 \\
\hline
\end{tabular}

Note: 1) Values in parentheses represent the $t$ value.

2) $\rho$ stands for the first-order autocorrelation coefficient in the error term.

3) The critical value of the t distribution based on 53 degrees of freedom for the demand system is 1.674 at $10 \%$ level, 2.006 at 5\% level, and 2.672 at $1 \%$ level. Additionally, *** and $* * *$ indicate that the estimated value is statistically significant at the $10 \%, 5 \%$ and $1 \%$ levels, respectively.

4) In column 1 , row $1, \mathrm{I}=$ Indonesia, $\mathrm{N}=$ Netherland, $\mathrm{C}=$ Côte d'Ivoire, $\mathrm{R}=$ Rest of the World.
Table 7. Price and Expenditure Elasticity of Demand for Cocoa Bean

\begin{tabular}{|c|c|c|c|c|}
\hline Price & Indonesia & $\begin{array}{c}\text { Côte } \\
\text { d'Ivoire }\end{array}$ & Ghana & $\begin{array}{l}\text { Rest of the } \\
\text { World }\end{array}$ \\
\hline Indonesia & $\begin{array}{l}-0.481^{* * * *} \\
(-4.945)\end{array}$ & $\begin{array}{l}-0.110 * * * \\
(-3.383)\end{array}$ & $\begin{array}{c}0.094 \\
(1.251)\end{array}$ & $\begin{array}{l}-0.091 * * \\
(-2.033)\end{array}$ \\
\hline Côte d'Ivoire & $\begin{array}{l}-1.072^{* * * *} \\
(-7.892)\end{array}$ & $\begin{array}{l}-0.433 * * * \\
(-6.866)\end{array}$ & $\begin{array}{l}-0.354^{* *} \\
(-2.126)\end{array}$ & $\begin{array}{l}-0.172 * * \\
(-2.063)\end{array}$ \\
\hline Ghana & $\begin{array}{c}0.023 \\
(0.217)\end{array}$ & $\begin{array}{c}0.011 \\
(0.178)\end{array}$ & $\begin{array}{l}-0.946 \text { *** } \\
(-4.068)\end{array}$ & $\begin{array}{c}-0.050 \\
(-0.938)\end{array}$ \\
\hline $\begin{array}{l}\text { Rest of the } \\
\text { World }\end{array}$ & $\begin{array}{l}-0.629 \text { *** } \\
(-5.332)\end{array}$ & $\begin{array}{c}0.011 \\
(0.217)\end{array}$ & $\begin{array}{l}-0.245^{* *} \\
(-2.394)\end{array}$ & $\begin{array}{l}-0.664 * * * \\
(-8.319)\end{array}$ \\
\hline Expenditure & $\begin{array}{l}2.159 * * * \\
(7.354)\end{array}$ & $\begin{array}{l}0.521 * * * \\
(5.361)\end{array}$ & $\begin{array}{l}1.451^{* * * *} \\
(8.927)\end{array}$ & $\begin{array}{l}0.977^{\text {**** }} \\
(5.981)\end{array}$ \\
\hline
\end{tabular}

Note: 1) The estimated elasticities are accompanied by the corresponding t values in parentheses.

2) The critical value of the t distribution based on 54 degrees of freedom for the demand system is 1.674 at $10 \%$ level, 2.005 at 5\% level, and 2.670 at $1 \%$ level. Additionally, $* *$ and $* * *$ indicate that the estimated value is statistically significant at the $5 \%$ and $1 \%$ levels, respectively.

\section{WORLD DEMAND FOR INDONESIA'S COCOA}

\section{Cocoa Bean}

We consider the global demand for cocoa bean in this section.

First, we consider own price elasticity. The result shows that own price elasticities of all the countries (Indonesia, Ghana, Côte d'Ivoire, and Rest of the World) are significantly negative and with absolute values under 1. Hence, if the price of Indonesia' cocoa bean was to decrease, the demand for Indonesia' cocoa bean would significantly increase. However, when the absolute value of own price elasticity is under 1 , reducing prices is not an effective strategy as a $1 \%$ decrease in prices increases export quantity by less than $1 \%$ thereby decreasing the export value. Therefore, it can be said that price reduction is not an effective strategy for all countries in the global cocoa bean market.

Second, we consider cross-price elasticity. The demand elasticities for Indonesia's cocoa bean relative to the cocoa bean price of Côte d'Ivoire and the Rest of the World are statistically significant, but have negative signs.

Additionally, elasticity of demand for Indonesia's cocoa bean to the cocoa bean price of Ghana is not significant. These results indicate that a reduction in prices of other countries' cocoa beans will not significantly decrease the demand for Indonesia's cocoa bean. Hence, it can be concluded that Indonesia has no competitor in the world cocoa bean market; Indonesia's cocoa bean is internationally competitive from the viewpoint of product differentiation.

Third, we estimate expenditure elasticities. The results reveal that each of the countries have positively significant expenditure elasticities and Indonesia leading 
Table 8. Price and Expenditure Elasticity of Demand for Processed Cocoa

\begin{tabular}{c|cccc}
\hline Demand & Indonesia & Netherland & $\begin{array}{c}\text { Côte } \\
\text { d'Ivoire }\end{array}$ & $\begin{array}{c}\text { Rest of the } \\
\text { World }\end{array}$ \\
\hline Price & & & & \\
\hline Indonesia & $-0.725^{* * *}$ & $-0.057^{* * *}$ & 0.035 & 0.002 \\
& $(-4.823)$ & $(-3.073)$ & $(0.590)$ & $(0.076)$ \\
Netherlands & $-1.065^{* * *}$ & $-0.240^{* * *}$ & $-0.432^{* *}$ & $-0.356^{* * *}$ \\
& $(-3.764)$ & $(-3.338)$ & $(-2.629)$ & $(-6.381)$ \\
Côte d'Ivoire & -0.066 & $-0.050^{* * *}$ & $-0.556^{* * *}$ & $-0.062^{* *}$ \\
Rest of the & $(-0.561)$ & $(-2.713)$ & $(-5.524)$ & $(-2.240)$ \\
World & -0.665 & $-0.239 * * *$ & $-0.384^{*}$ & $-0.637^{* * *}$ \\
Expenditure & $(-1.583)$ & $(-3.544)$ & $(-1.751)$ & $(-7.316)$ \\
& $2.521^{* * *}$ & $0.587^{* * *}$ & $1.338^{* * *}$ & $1.053^{* * *}$ \\
\hline
\end{tabular}

Note: 1 ) The estimated elasticities are accompanied by the corresponding $t$ values in parentheses.

2) The critical value of the $t$ distribution based on 53 degrees of freedom for the demand system is 1.674 at $10 \%$ level, 2.006 at 5\% level, and 2.672 at $1 \%$ level. Additionally, *,** and $* * *$ indicate that the estimated value is statistically significant at the $10 \%, 5 \%$ and $1 \%$ levels, respectively.

with the highest value of 2.159 followed by Ghana (1.451), Rest of the World (0.977), and Côte d'Ivoire (0.521).

When the world expends more on cocoa bean, Indonesia gains the highest revenue compared to the other countries. This implies that Indonesia has the biggest competitive advantage in expanding exports of cocoa bean compared to the other countries.

Fourth, we examine the dummy variable parameter. The coefficient of the dummy variable in Indonesia's share equation for cocoa bean has a significantly negative value $(-0.155)$. This implies that the policy introduction significantly decreased the export of Indonesia's cocoa bean.

\section{Processed Cocoa}

We consider the world demand for processed cocoa in this section.

First, we consider own price elasticity. The results reveal that the own price elasticities of all countries (Indonesia, Netherlands, Côte d'Ivoire, and the Rest of the World) are significantly negative with absolute values under 1. Hence, as explained in previous section, it can be concluded that price reduction is not an effective strategy for all countries in the world market of processed cocoa.

Second, in terms of cross-price elasticity, the elasticity of demand for Indonesia's processed cocoa to the price of Netherlands processed cocoa is significant but has a negative sign. Additionally, the elasticities of demand for Indonesian processed cocoa to the processed cocoa price of Côte d'Ivoire and the Rest of the World are not significant. Hence, as mentioned in previous section, it may be concluded that Indonesia has no competitor in the world market of processed cocoa, and Indonesia's processed cocoa is internationally competi- tive from the viewpoint of product differentiation.

Third, we consider expenditure elasticity. The results reveal that each of the countries have positively significant expenditure elasticities with Indonesia leading with a value of 2.521, followed by Côte d'Ivoire (1.338), the Rest of the World (1.053), and Netherlands (0.587). Indonesia gains the highest income compared to other countries when global expenditure on processed cocoa increases. This indicates that Indonesia is in the most advantageous position when it comes to expanding exports of processed cocoa compared to the other countries.

Fourth, we examine the dummy variable parameters. The coefficient of the dummy variable of Indonesia's share equation for processed cocoa is significantly positive (0.021) suggesting that the policy implementation significantly increased the export of Indonesia's processed cocoa. Based on this result, the aim of the Indonesian government to increase export of processed cocoa seems to have succeeded.

\section{Comparison of Results for Cocoa Bean and Processed Cocoa}

We consider the appropriateness of the policy introduced by the Indonesian government by comparing the estimation results of Indonesian cocoa bean and processed cocoa (Table 9).

Both cocoa bean and processed cocoa have significantly negative values for own price elasticity. Hence, if the price of Indonesian cocoa bean or processed cocoa changes, the demand for them would also change. In addition, the absolute value of own price elasticity of processed cocoa $(-0.725)$ is higher than that of cocoa bean $(-0.481)$; therefore, processed cocoa offers the better value for export expansion.

From a competitive standpoint, Indonesian cocoa bean and processed cocoa have no competitors because a price decrease in other countries will not significantly decrease the demand for Indonesia's cocoa bean and processed cocoa. Hence, it can be said that Indonesia's cocoa products are differentiated and do not compete with other countries. In other words, we can claim that Indonesia's cocoa bean and processed cocoa are internationally competitive from a product differentiation viewpoint. This may potentially be the case as Indonesia's cocoa differs from that of Côte d'Ivoire and Ghana.

In terms of expenditure elasticity, both Indonesia's cocoa bean (2.159) and processed cocoa (2.521) are positively significant. Although both products have sig-

Table 9. Comparison of Results for Cocoa Bean and Processed Cocoa

\begin{tabular}{ccc}
\hline & Cocoa Bean & Processed Cocoa \\
\hline Own price elasticity & $-0.481^{* * *}$ & $-0.725^{* * *}$ \\
Competitor & No & No \\
Expenditure elasticity & $2.159^{* * *}$ & $2.521^{* * *}$ \\
\hline
\end{tabular}

Note: $* * *$ indicate that the estimated value is statistically significant at the $1 \%$ level. 
nificant values, processed cocoa has a greater potential to earn more revenue than cocoa bean when global expenditure increases.

Based on the above comparison, we can claim that Indonesia's processed cocoa has greater potential for export expansion than cocoa bean. Therefore, the policy introduced by the Indonesian government is appropriate and in accordance with the purpose of the policy to increase and develop the cocoa industry.

\section{CONCLUSION}

In this study, we consider the international competitiveness of Indonesia's cocoa bean and processed cocoa by estimating world demand for each of these separately. The main analysis results are as follows.

First, each of Indonesia's cocoa bean and processed cocoa is product differentiated from other export countries' products, respectively.

Second, expenditure elasticities of Indonesia's cocoa bean and processed cocoa are the highest among all export countries' products, respectively.

Third, the policy change in 2010 significantly decreased the expenditure share of Indonesia's cocoa bean and significantly increased the expenditure share of Indonesia's processed cocoa in terms of global demand.

Fourth, it can be claimed that the policy introduced in 2010 by the Indonesian government is appropriate because Indonesia's processed cocoa shows a greater potential to be considered for export expansion than its cocoa bean.

Based on these results, we put forth policy recommendations. The policy implemented since 2010 by the Indonesian government seems to be appropriate because Indonesia's processed cocoa shows the higher potential than cocoa bean for export expansion. Although this policy is suitable for Indonesia's cocoa industry, the farm gate price remains low following the policy change. This may be due to the market power of the cocoa industry in Indonesia. The Indonesian government would still need to soften the market power in order to benefit not only the government and industry, but also the farmers.

\section{AUTHOR CONTRIBUTIONS}

Virda ZIKRIA designed the study, corrected and ana- lyzed the data, and wrote the paper, Kohya TAKAHASHI assisted in designing the study, analyzing the data and writing the paper, and Koshi MAEDA designed and supervised the whole of study.

\section{ACKNOWLEDGEMENTS}

This paper is one study supported by JSPS KAKENHI Grant Number JP16K18758.

\section{REFERENCES}

Asselstine, M., J. M. Mollo, J. M. Morales and V. Papanikolopoulos 2016 Cocoa Liquor, Butter, \& Powder Production. Senior Design Reports (CBE), Department of Chemical and Biomolecular Engineering, University of Pennsylvania, US

Deaton, A. and J. Muellbauer 1980 An Almost Ideal Demand System. American Economic Review, 70: 312-326

FAOSTAT 2017 Food and Agriculture Data. Available at: www.fao. org/faostat/en (accessed 13 June 2017)

Honma, M. 1983 The Demand Structure of World Wheat Trade: A Trade Flow Model Approach. Journal of Rural Economics, 55: $74-81$

Indonesia-investments 2017 Cocoa. Available at: www.indonesia-investments.com/business/commodity/cocoa (accessed 23 November 2017)

Indonesian Ministry of Finance 2010 Minister of Finance Regulation Number 67/PMK.011/2010

International Monetary Fund 2017 International Financial Statistics. Available at: www.imf.org/data/imf-finances (accessed 15 August 2017)

Konandreas, P., P. Bushnell and R. Green 1978 Estimation of Export Demand Functions for U.S. Wheat. Western Journal of Agricultural Economics, 3: 39-49

Ragimun 2012 Analisis Daya Saing Komoditas Kakao Indonesia (Analysis the Competitiveness of Indonesia's Cocoa). Jurnal Pembangunan Manusia (Human Development Journal), 6 : $171-190$

Rifin, A. 2013 Competitiveness of Indonesia's Cocoa Beans Export in the World Market. International Journal of Trade, Economics and Finance, 4: 279-281

Spiegel, A. 2014 What's The Deal with Cocoa Butter. The Huffington Post, 24 October, 14. Available at: www.huffingtonpost.com/2014/10/24/cocoa-butter (accessed 20 July 2017)

United Nations 2017 Comtrade. Available at: www.comtrade.un. org/data (accessed 13 June 2017)

UTZ 2017 Conversion Ratio. Available at: www.utz.org/betterbusiness/ (accessed on 21 July 2017)

Yen, S. T. and W. S. Chern 1992 Flexible Demand Systems with Serially Correlated Errors: Fat and Oil Consumption in the United States. American Journal of Agricultural Economics, 74: $689-697$ 
